\title{
Applying an Experiential Learning Model to the Teaching of Gateway Strategy Board Games
}

\author{
Aiko Sato \\ International Relations Department, University of Shizuoka, Shizuoka, Japan \\ caramel.macchiato.25@gmail.com
}

\section{Jonathan de Haan}

Dr., (corresponding author), International Relations Department, University of Shizuoka, Shizuoka, Japan,dehaan@u-shizuoka-ken.ac.jp

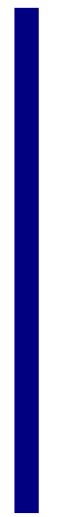

\begin{abstract}
The board game hobby has rapidly grown and evolved in recent years, but most of the non-digital games lack tips and tutorials and remain difficult to learn and teach effectively. In this project, we integrated a popular hobbyist approach to teaching modern strategy games with classical experiential learning elements (i.e., demonstration, observation, reflection, discussion and repeated experiences). We tested our model by teaching two modern board games to Japanese high school and university students. Questionnaires, gameplay data, self-ratings and discussions showed improved understanding and enjoyment, more strategic play and more interest in modern board games over the course of the instructional sequence. The model's repetition (the participants played each game three times) was rated the most useful in terms of learning the games. Overall, the integrated model was largely successful in teaching strategy board games to new players, and we offer several recommendations for teachers, designers and researchers of board games.
\end{abstract}

Keywords: experiential learning, board games, effective instruction, cognitive load, novice learners

\section{INTRODUCTION}

Board games have been played for more than 5,000 years (Piccone, 1980) and the hobby board game industry has grown every year from 2008 to 2014 (ICv2, 2014). Modern board games are not the "roll and move" experiences most children grew up with; analog game designers are experimenting with new mechanisms and fixing traditional design elements of board games (Nicholson, 2008). Many people learn and enjoy modern board games with friends and family, and some even benefit educationally (Hinebaugh, 2009; Hirsh-Pasek \& Golinkoff, 2008; Kemp, Smith, Dekoven \& Segal, 2013) but players need to learn and be able to teach them and this can be very difficult (Daviau, 2013, as cited in Smith, 2014). This project investigated how to best teach analog games for maximum understanding and enjoyment. 


\section{REVIEW OF LITERATURE}

\section{The difficulty of learning modern board games}

Cognitive load theory (Sweller, van Merriënboer, \& Paas, 1998) is based on how various media elements are processed by (and can overload) the brain's limited working memory. The mechanisms, actions and interrelated systems of board games (e.g., managing a hand of cards, evaluating a map on the board, remembering legal and illegal moves in the game, keeping track of score, remembering win conditions) and the complex and interdependent text, examples and diagrams in rule books can be very difficult, especially for new players without proper guidance, and these can require very high mental effort and hinder understanding and learning (Brown, 2011; Kalyuga \& Plass, 2009).

While digital games are interactive and can include dynamic instructional strategies to expertly teach players complex digital games (Anderson et al., 2012; Gee, 2003, Pinelle et al., 2008; Squire, 2011), board game systems and rules are not interactive; they cannot adjust themselves (as computer-driven tutorials and tool tips can) to support or match the reader's experience or understanding of analog game play. Board game rules (textual instructions on paper) must be read, understood, and mentally organised in order to teach and play the game smoothly. Rob Daviau, a board game industry veteran, jokes that "board games are the only hobby that see you need to pass a written and speaking exam before you start" (Daviau, 2013 as cited in Smith, 2014). If these complex board game rules are not read or taught correctly, the game cannot begin or continue smoothly.

On top of the fact that "learning ... games from a piece of paper is notoriously difficult" (Gobet, de Voogt, \& Retschitzki, 2004, p. 164), many rulebooks are not constructed in a way to facilitate learning or teaching of game systems; "Gobet and Jansen (2006) argue that [rule] books often violate sound psychological and pedagogical principles" (p. 21). Many rule books of modern board games are descriptions of actions and lists of rules rather than a systematic introduction and building on concepts that players need to know to start playing and deepen abilities. One reason for the poor quality of many rules is that "instruction books are written and methods are [not] developed by ... educationalists" (e.g., Dextreit \& Engel, 1981 as cited in Gobet, de Voogt, \& Retschitzki, p. 163-4) and "few [are based...on] scientific theories (Gobet, de Voogt, \& Retschitzki, p. 166).”

\section{Teaching board games}

Since modern board games can be so difficult, players "require considerable external support to build new knowledge structures in a relatively efficient manner" (Kalyuga \& Plass, 2009, p. 723). Thus, emphasis must be placed on effective face-to-face teaching. Gobet and Jansen (2006) explain how board game teachers can assist with both "a technical contribution: a selection and preparation of study material, identification and remediation of trainee's weaknesses, feedback on performance, and advice" (Gobet, de Voogt, \& Retschitzki, p. 168) and also a "personal contribution: management of the trainee's motivation, and optimisation of study time." Other educational researchers 
explain how a teacher's "direct instructions and guidance can perform an executive role" (Kalyuga \& Plass, 2009, p. 723) thereby reducing the effort of learning a new game.

Studies have evaluated the theoretical claims made above regarding the effect of teachers and guides on learning a new game. For example, N'Guessan Assande (1992, as cited in Gobet, de Voogt, \& Retschitzki, p. 164-165) taught awale to a group of nongamer students and a group of chess players using three methods "(a) practice without help" for 10 hours, "(b) observation of an expert player (5 hours), then practice (5 hours)" and "(c) a demonstration and an explanation of the key concepts (5 hours), then practice (5 hours)." The third condition, "demonstration and explanation of concepts," was the most effective. Educational researchers offer some advice, such as: "instruction to beginners and instruction for the purpose of becoming better should be separate" (Dollekamp, 1985 as cited in Gobet, de Voogt, \& Retschitzki, p. 164) and "more help should be provided initially when players are less experienced, and this help should be faded out as the players progress and acquire new skills" (Renkl, Atkinson, \& Große, 2004).

One example of a teaching framework by an experienced gamer and educator that seeks to elevate the learning of new modern games is Sturm's "How to teach games: A general primer" (2008). Sturm's first step (2008, "The Hook" section) involves telling players "what the game is about, how [to] play, and how [to] win" as soon as possible." He warns teachers "not to summarise the rules as written in the rule book... [as] rulebooks are boring to most people." The goal is to motivate and not to overload players. His second step (2008, "The Meat" section) is the "main part" and involves "explaining how a player plays his turn," "the [elements] that are essential to the general play of the game," "how the game is ended," and "how the game is won" for the purpose of "get[ting] started with the game" as soon as possible. Sturm (in line with Dollekamp, 1985) suggests telling players that just-in-time guidance will be offered during the game. Sturm's third step (2008, "How Can I Win?" section) is the time to "give general strategy tips, common beginner pitfalls, and typical long term strategies" in order to give "[first-time] players, especially non-gamers, ... a few basic frameworks to try to follow to succeed in the game." Sturm expertly balances freedom of experience (letting players find strategies on their own) and supportive feedback in his instructional methods. Sturm also offers useful advice for guiding new players during their first games (2008, "The Color Commentary" section). Several of his points are aimed specifically at lowering players" "verbal information overload" by "tak[ing] one or two elements of complexity away from the game ... to make the game a more enjoyable experience and ... [to make the players] more willing to play the game again with the full rules." Sturm advises teachers not to play the game for the students, to respond to requests for advice by "explain[ing] the situation and point[ing] out various options," to let them make mistakes ("this is how they will learn"), and to encourage new players to watch the other players. Sturm's framework seems to be one of the best ways for teachers to reduce the mental effort of learning and playing a new game and to ensure enjoyable gameplay experiences. 
We were struck by the common thread of experience in the theories, research and practice of game instruction, for example, "learning by doing, being told, and observing are intrinsic to the teaching system [of mancala]" (Gobet, de Voogt, \& Retschitzki, p. 164) and Sturm urges teachers to let students learn by doing as soon as possible, to let students observe expert play, to let them make mistakes and to offer just-in-time advice and feedback. In this research project, we continued to explore these themes by building more elements of classical experiential learning into the teaching of modern board games.

\section{Experiential Learning and Board Game Teaching and Learning}

In this project, we integrated various approaches in board game education (especially Sturm's) with a foundational experiential learning approach (Dewey, 1938; Kolb, 1984). For Dewey, learning is "intelligently directed development" (Dewey, p. 69) requiring careful design and guidance by teachers. Our players would not only be learning the rules of the games, but interacting with the systems and other players in a direct way, which would provide many opportunities for discussion and reflection to "grasp and transform their experience" into knowledge (Kolb, p. 41). Limiting instruction to the very basics and asking the players to attempt the game as soon as possible can quickly create an experience on which learning can be continued through and after the game.

As Dewey writes, one's present experience connects one's past and future; we wanted our players (who had few prior game experiences) to learn and enjoy the games well in order to possibly continue playing modern games. For Dewey, social experience, human contact, interpersonal communication, and sharing ideas are crucial for learning to be meaningful and effective. The reflection and social interaction of our instructional sequence were important to help the players move from reliance on the game teacher to reliance on themselves, moving them in and through the "zone of proximal development" (Vygotsky, 1978).

Kolb's four learning modes, Concrete Experience, Abstract Conceptualization (grasping), Reflective Observation and Active Experimentation (transforming) provided us with steps to structure instruction to give the players tension and a base for learning: experiencing, reflecting, thinking and acting again. Our instructional model asked players to (in order): just play, then talk about strategies, then watch others and talk and then try new strategies. The experiential learning cycle prompts learners to create and recreate knowledge (Kolb and Kolb, 2009) to develop their game playing over time.

The post-experience stages are critical for developing understanding and ability. Schon (1983) contrasts reflection in the moment (which is difficult to do while playing a complex game) and about the moment (chatting after a game is finished). The debriefing (reflection and discussion) stage, the "heart and soul" of experiential learning (Rall et al, 2000), should be guided by a facilitator (e.g., a teacher) to focus players on the learning objectives. There are many models of debriefing (Crookall, 2010; Nicholson, 2012) but most require participants to describe, analyse, and apply experience and knowledge.

Since knowledge is not a product but, rather, a process developed over time (Kolb and Kolb, 2009), and many players initially "satisfice" (Simon, 1990..."Satisfy the 
requirements" [finish the game] yet "sacrifice some elements of performance" (Simon, 1956 as cited in Argyris and Schon, 1996), we also incorporated the experiential "double loop" learning process in which errors were made during the first loop (e.g., playing a game for the first time) are addressed in the debriefing and then corrected in a second game.

"In spite of extensive technical literature, little empirical evidence is available about the merits of the proposed methods" (Gobet, de Voogt, \& Retschitzki, p. 169). The purpose of the current study was to evaluate a new model of board game instruction that combines hobbyist best practices with established experiential learning approaches. We collected quantitative and qualitative data on new board gamers' understanding, strategy-making and enjoyment of two games to assess and improve our pedagogical model.

\section{METHOD}

\section{Research Questions}

1. Do the students improve their board game skills? How do the students' strategies change or develop?

2. How do they improve their skills? Was the experiential learning model helpful for learning how to play the games? If so, which elements were most helpful?

3. What are the students' opinions about these modern gateway board games?

\section{Participants}

This project was conducted at a public university in a large Japanese city with two high school students (one 16 year old female and one 17 year old male) and two university students (both 20 year old females). All the participants liked board games, but had not played many modern board games. The high school students had played card games, roll and move games, shogi, chess and othello. One was aware of "The Game of Life" but had not played it. They reported liking board games. The university students had played "The Game of Life," shogi, chess, and othello, and one had played "The Resistance" (a modern social card game). They also had positive opinions of playing board games.

\section{Board Games}

Because of the participants' inexperience with modern board games, appropriate "gateway games" (Ross, 2011) were selected. The hobbyist term "gateway game" refers to a game that can bring a beginner into the hobby. Good gateway games are simple, meaningful, offer interesting choices, take the players' gaming histories into account, and are interesting to both the instructor and the new player (Ross). This study used two gateway games: "Hey, That's My Fish!" (Jakeliunas, 2003), a chess-like game in which the players move cute penguin figures to capture and remove hexagonal fish tiles, and "Ticket to Ride" (Moon, 2004), a rummy-style game in which players collect and use coloured cards to place their train pieces on North American train routes to connect cities and score points. Both are highly rated as family, abstract and gateway games by 
the board game community (https://boardgames/familygames/browse/boardgame, https://boardgamegeek.com/thread/635360/best-gateway-games-top-100-contestresults).

\section{Procedure and Instruments}

(1) On the first day, a short demonstration was given to familiarise players with the game and explain the goal of the game and the actions they could take. Students began playing immediately to have a concrete experience. During play, the teacher acted as a facilitator to give advice or help. Following the play, a questionnaire helped students gauge their understanding and a discussion helped students reflect on gameplay and share ideas. Then, players thought about the game and planned for the next gameplay experience.

(2) On the second day, students shared their strategies and then immediately played the game again. After the game, a questionnaire helped them again gauge their understanding and another discussion let students share and refine their ideas. Then, players needed to continue to think about the game and plan for the next game.

(3) On the third day, the teacher shared some expert strategies. Students needed time to integrate these advanced strategies into their gameplay, so planning time was given. Students played the game third time, then used a questionnaire again to gauge understanding and a discussion again helped students share and learn from their experiences.

After an informed consent was given, a demographics questionnaire was given. A digital video recorder recorded all of the instruction, gameplay and discussions. Notes were also taken (e.g., about scores and turns). Questionnaires were administered after each game was played in order to learn more about the students' experiences and opinions.

\section{FINDINGS}

The comments have been translated from Japanese into English by the authors.

Question 1: Do the students improve their board game skills? How do the students' strategies change or develop?

The players did improve their skills, both in terms of length of game (see Table 1; subsequent games were played more quickly) and self-rated understanding (see Table 2; understanding was finally perfect). Players first played carefully and slowly, but gradually played more smoothly. They grew knowledgeable and accustomed to the games.

Table 1: Timed Duration of Each Game in the Experiential Learning Sequence

\begin{tabular}{llll}
\hline & $1 s t$ & $2 n d$ & $3 r d$ \\
\hline Hey That's My Fish & 15 minutes & 10 minutes & 6 minutes \\
\hline Ticket to Ride & 63 minutes & 48 minutes & 50 minutes \\
\hline
\end{tabular}


Table 2: Reported Understanding of Each Game in the Experiential Learning Sequence

\begin{tabular}{lllll} 
& Before playing & $1 s t$ & $2 n d$ & $3 r d$ \\
\hline Hey That's My Fish & $83.3 \%$ & $100 \%$ & $100 \%$ & $100 \%$ \\
\hline icket to Ride & $72.5 \%$ & $88.75 \%$ & $92.5 \%$ & $100 \%$ \\
\hline
\end{tabular}

In "Hey, That's My Fish!," each student had and changed strategies. One student first targeted "three fish" tiles, but lost, so he next tried to make islands of tiles. He was not satisfied with his score, so he divided his penguins between making islands and capturing points. He won, and learned the importance of reflecting, hearing other members' opinions, and being flexible. He reflected "at first I got confused many times, but I could gradually understand it well and enjoyed this game a lot." Another student blocked other players and won her first game. To be more strategic, she carefully considered the initial piece placement and ignored removing other penguins. She finally balanced making islands, capturing fish and attacking others and won her game. Both ended up finding a mindful balance between their various approaches.

Strategies in "Ticket to Ride" were developed to manage the luck of the destination cards (which can either reward or penalise players at the end of a game). For example, one male student first tried to build routes after collecting many cards, but ran out of time to use his destination cards. He learned, then, how to foil others and how to earn end game bonuses. In the second game, he claimed common routes and made long paths of trains, earning the bonus, avoiding penalties and won the game. In the final game, he completed short routes quickly, made many other routes, got the bonus again and won the game. He seemed to think deeply in order to develop his abilities.

Question 2: How do they improve their skills? Was the experiential learning model helpful for learning how to play the games? If so, which elements were most helpful?

The general instructional sequence was divided into five elements: (1) demonstration, (2) watching other players' play, (3) playing 3 times, (4) talking with other players and (5) reflecting after playing. The students ranked the elements of the lesson in terms of usefulness ( 5 points for the most useful and 1 point for the least useful element). The order was similar for both games, with repetition (playing 3 times) ranked the highest and demonstration ranked the lowest. The specific point tallies can be seen in Table 3 .

Table 3: Reported Perceived Usefulness of Instructional Sequence Elements

\begin{tabular}{ll}
\hline Hey That's My Fish sequence & Ticket to Ride sequence \\
\hline playing three times (16 points) & playing three times (19 points) \\
\hline talking with other players (13 points) & watching other players' play (11 points) \\
\hline watching other players' play (11 points) & talking with other players (11 points) \\
\hline
\end{tabular}




\begin{tabular}{ll} 
reflecting after playing (11 points) & reflecting after playing (10 points) \\
\hline demonstration ( 9 points $)$ & demonstration (9 points) \\
\hline
\end{tabular}

The experiential learning model seemed very effective; students' skills developed in each subsequent game (refer to the data in Tables 1 and 2). It seemed difficult for players to understand everything before playing (after only receiving a demonstration and explanation). Student comments such as "I played three times and I learned these board games well and deeply" and "I was able to plan the game this time by making full use of the previous play" corroborate their high ranking of repetition. They were very curious about other players, too, and made comments such as "other players' opinions and reflections were useful," and "I was aware of other players' play during the whole game and learned a lot from them," and "it's important to look at others and plan my play."

Question 3 What are the students' opinions of these modern gateway board games?

All of the students had positive opinions and comments about both of these games. Enjoyment of "Hey, That's My Fish" was 100\% each time, and reported enjoyment of "Ticket to Ride" began very high and grew to $100 \%$ in subsequent plays (see Table 4).

Table 4: Reported Enjoyment of Each Game

\begin{tabular}{llll}
\hline & 1 st & 2nd & 3rd \\
\hline Hey That's My Fish & $100 \%$ & $100 \%$ & $100 \%$ \\
\hline Ticket to Ride & $91.7 \%$ & $100 \%$ & $100 \%$ \\
\hline
\end{tabular}

One student remarked that "Hey, That's My Fish" "is simple but really strategic like Shogi. It was interesting." Before playing "Ticket to Ride," students had not understood it completely, but after the next plays, the understanding and enjoyment were both $100 \%$; "at first, it seemed very difficult, but once I learned how to play it, it was enjoyable."

\section{DISCUSSION}

\section{Cognitive load}

The teaching sequence was designed to reduce the players' mental effort (e.g., players did not have to read the rules and received just-in-time guidance), but they still experienced initial difficulty with both games, though the cognitive load seemed to lower after the concrete experience (Kolb, 1984) of playing and having the repeated debriefings. The players' experience of learning and playing these games might be related to the number of elements and rules (i.e., complexity) in the games. "Ticket to Ride" has a large map with routes, colours and points to process, a score track, three possible actions each turn, an end-game scoring sequence, and hidden information. "Hey That's My Fish" has a smaller board with only one action per turn, simpler end-game 
scoring and no hidden information. Boardgamegeek.com users rate the weight (i.e., complexity) of "Hey That's My Fish" as 1.5 out of 5.0 and the weight of "Ticket to Ride" as 1.9 out of 5.0, which can also explain our players' better initial understanding of "Hey That's My Fish."

\section{The importance of good teaching}

The careful, "intelligently directed" (Dewey, 1938, p. 69) instructional sequence and teaching helped students completely understand and enjoy the games. Dollekamp's (1985) and Sturm's (2008) advice to first focus on basic elements of a game was very helpful; our players started playing using simple instructions and experimented with and learned advanced tactics later in the lesson. We also found Sturm's advice to learn as much as possible about the games' rules, technicalities, strategies and pitfalls before working with our players to be very useful. Although demonstrations and explanations were rated most helpful in a study of chess instruction (N'Guessan Assande, 1992), our players rated demonstration to be not as useful as playing three times or discussing the game with other players. This difference may be due to the dissimilar complexities or themes (i.e., chess is more abstract) of the games.

\section{Experiential learning model}

Our students benefited from the various elements and overlaps in experiential learning elements and a teacher-hobbyist approach to teaching board games. Both Kolb (1984) and Sturm (2008) stressed the importance of immediate experience for testing ideas. The simple information that we gave our players was enough for them to try the games then reflect on and effectively build on the initial experience in future plays. The improvement in the self reports can be attributed to the reflection and discussions; as Thiagarajan clearly states, our players "learn[ed] from reflecting on their experience" (2004, Debriefing Section). More complex games might require more debriefing by teachers. Our project provides strong support for Dewey's (1938) arguments that social experience, human contact, interpersonal communication, and sharing ideas are crucial for learning to be meaningful and effective, as evidenced by comments such as "I was aware of other players' play during the whole game and learned a lot from them." The "imperfect" initial plays and ratings show that the players did somewhat "satisfice" (Simon, 1990) and benefited from the repetition in the sequence in order to correct errors and retest ideas; as students stated: "I played three times and I learned these board games well and deeply" and "I was able to plan the game this time by making full use of the previous play." Our players transformed initial experiences into understanding and strategies in future plays (Kolb, 1984) and did not need as much help from the teacher or others (in line with Vygotsky, 1978) as the lesson continued.

\section{Gateway games}

Dewey's framework for how experiences link past and future knowledge is useful for analysing our players' experiences. Our students had known only a few classic games, but in the project they learned about a new style of game (relating them to prior knowledge, e.g., ““'Hey, That's My Fish” is simple but really strategic like Shogi”) and learned and played them well and enjoyably with their peers. The players' past 
experiences influenced how they experienced our teaching model and the games, and also set the stage for future learning. Students showed enthusiasm for continuing to experience these kinds of games, for example, "I'd like to try more of this kind of modern board game." We believe that we succeeded in "provid[ing] them with experiences which will help to open up, rather than shut down, [their] access to future growth experiences" (Neill, 2005) and see the potential for the students to continue to learn and enjoy modern board games.

We found that both "Hey, That's My Fish!" and "Ticket to Ride" meet all of Ross' (2011) gateway game criteria, though our players seemed to have more difficulty understanding and enjoying "Ticket to Ride." Even though "Ticket to Ride" is the \#1 gateway game on Boardgamegeek, "Hey That's My Fish" might be better for players completely new to modern board games: it is a shorter game, the figures are very attractive, and moving the pieces like those in chess might help players understand and enjoy the game more quickly. Based on our data, "Ticket to Ride" might be an excellent second game.

\section{Limitations}

The generalisability of the results of this study may be limited because the use of self report data, possible inadequacies in the explanation and demonstration of the games, and the use of only two games in the project with four students in total.

\section{CONCLUSION}

In general, this project's results demonstrate the need to compensate for or to modify the traditional instructional materials and methods of board games. The project's experiential learning model can make teaching and learning games more effective and enjoyable.

Teachers of board games should prepare fully and give players immediate experiences and multiple chances to receive feedback and discuss strategies with other players. Some players might even benefit from first playing as pairs, as Squire (2011) suggests, to require verbalization of strategies to each other and the teacher. For children and novice players, we strongly recommend simplifying aspects of a game (e.g., streamlining scoring, reducing actions, excluding confusing rule exceptions) until the players understand and enjoy a base game and are interested in a complete game experience with additional elements in subsequent plays. Playing a few moves as a group (the teacher and players discussing all of the initial moves) might be a good approach to ease players into a difficult game as well. Teachers should learn as much as possible about their students' gaming experiences and preferences and select and teach games that connect with that past experience. Although players may want to immediately try advanced aspects of a game, teachers should focus on the core systems of a game before teaching expert strategies or mechanisms to ensure everyone's understanding and enjoyment.

Board game designers and companies can also benefit from our results. Instead of rule books being reference manuals or lists of rules, they might give new players a simple 
narrative or conceptual framework and immediate actions and goals to get started, and then build in complicated rules and actions as players become more knowledgeable. Rule books might include short scripts for one player to read that include the core elements that Sturm suggests, as well as specific questions for the group to discuss following play. Designers and companies could also break down difficult games into smaller modules for groups of players to master in sequence. Rule books could also include hints for beginners (i.e., elements to focus on and elements to ignore), examples of common mistakes and pitfalls to avoid, and more advanced strategies and tactics for skilled players.

Further research might test this learning model with other gateway games, modern card games, and more complicated strategy games. Other projects might explore different explanation or demonstration methods (e.g., scripts, videos, or playing a few rounds as a group). Another study might investigate cognitive load effects of the games by utilising think-aloud protocols during gameplay or use post-game instruments (e.g., Paas, 1992). Researchers should continue to identify complex aspects of games for which effective instructional approaches can be developed to assist players in their understanding and enjoyment of new types of games.

\section{REFERENCES}

Ackroyd, T. (2011). The best gateway games - the top 100 - contest results. Retrieved from: http://boardgamegeek.com/thread/635360/the-best-gateway-games-the-top-100contest-res.

Andersen, E., O'Rourke, E., Liu, Y. E., Snider, R., Lowdermilk, J., Truong, D., ... \& Popovic, Z. (2012, May). The impact of tutorials on games of varying complexity. In Proceedings of the SIGCHI Conference on Human Factors in Computing Systems (pp. 59-68). ACM.

Argyris, C., \& Schon, D. A. (1996). Organizational learning II. Boston: Addison Wesley.

Board Game Geek. (n.d.). Hey, That's My Fish! Retrieved from: http://www.boardgamegeek.com/boardgame/8203/hey-thats-my-fish.

Board Game Geek. (n.d.). Ticket to Ride. Retrieved from: http://www.boardgamegeek.com/boardgame/9209/ticket-to-ride.

Brown, J. F. (2011). The Skills System Instructor's Guide: An Emotion-Regulation Skills Curriculum for All Learning Abilities. IUniverse.

Crookall, D. (2010). Serious games, debriefing, and simulation/gaming as a discipline. Simulation \& gaming, 41(6), 898-920.

Daviau, R. (2013). as cited in Smith, Q. (2014, January 6). GAMES NEWS! 06/01/14. [Web log comment]. Retrieved http://www.shutupandsitdown.com/blog/post/games-news-060113/

Dewey, J. (1938). Experience and education. New York: Simon and Schuster. 
Hinebaugh, J. P. (2009). A board game education. R\&L Education.

Hirsh-Pasek, K. \& Golinkoff, R. (2008). Why Play = Learning. Retrieved from: http://www.child-encyclopedia.com/documents/Hirsh-Pasek-GolinkoffANGxp.pdf

ICv2. (2015, February 26). Six Straight Growth Years in Hobby Games. [Web log comment]. Retrieved from: http://icv2.com/articles/news/view/30959/six-straightgrowth-years-hobby-games

Gee, J.P. (2003). What video games have to teach us about learning and literacy. New York: Palgrave Macmillan.

Gobet, F., \& Jansen, P. J. (2006). Training in chess: A scientific approach. In T. Redman (Ed.), Chess and education (pp. 81-97). Dallas, TX: University of Texas.

Gobet, F., Retschitzki, J., \& de Voogt, A. (2004). Moves in mind: The psychology of board games. Psychology Press.

Jakeliunas, A. (2003). Hey, That's my Fish! [Board Game]. Mayfair.

Kalyuga, S., \& Plass, J. L. (2009). Evaluating and managing cognitive load in games. Handbook of research on effective electronic gaming in education, 2, 719-737.

Kemp, G., Smith, M., Dekoven, B. \& Segal, J. (2013). Play, Creativity, and Learning: Why Play Matters for Kids and Adults. [online] Retrieved from: http://www.helpguide.org/life/creative_play_fun_games.htm

Kolb, D. (1984). Experiential learning; Experience as the source of learning and development. Englewood Cliffs, NJ: Prentice Hall.

Kolb, A. \& Kolb, D. (2009). Experiential learning theory: a dynamic, holistic, approach to management learning, education and development. In S. J. Armstrong \& C. V. Fukami (Eds.), The SAGE handbook of management learning, education and development. Sage.

Moon, A.R. (2004). Ticket to Ride. [Board Game]. Days of Wonder.

Neill, J. (2005). 500 word summary of John Dewey's "Experience \& Education". [online] Retrieved from: http://wilderdom.com/experiential/SummaryJohnDeweyExperienceEducation.html.

Nicholson, S. (2008). Modern board games; It's not a Monopoly any more. Library Technology Reports 44(3). 8-10, 38-39.

Nicholson, S. (2012). Completing the Experience: Debriefing in Experiential Educational Games. Proceedings of The 3rd International Conference on Society and Information Technologies. Winter Garden, Florida: International Institute of Informatics and Systemics. 117-121.

Paas, F. (1992). Training strategies for attaining transfer of problem-solving skill in statistics: A cognitive-load approach. Journal of Educational Psychology, 84, 429-434.

Piccione, P. (1980). In Search of the Meaning of Senet. [online] Available http://www.gamesmuseum.uwaterloo.ca/Archives/Piccione/index.html 
Pinelle, D., Wong, N., \& Stach, T. (2008, April). Heuristic evaluation for games: usability principles for video game design. Proceedings of the SIGCHI Conference on Human Factors in Computing Systems (pp. 1453-1462). ACM.

Rall, M., Manser, T., \& Howard, S. K. (2000). Key elements of debriefing for simulator training. European Journal of Anaesthesiology, 17(8), 516-517.

Renkl, A., Atkinson, R.K., \& Große, C.S. (2004). How fading worked solution steps works-A cognitive load perspective. Instructional Science, 32, 59-82.

Ross, D. (2011). Top 5 gateway games. [online] Retrieved from: http://boardgameforge.wordpress.com/2011/12/05/top-5-gateway-games

Schön, D. A. (1983). The reflective practitioner: How professionals think in action (Vol. 5126). Basic books.

Simon, H. A. (1990). Invariants of human behavior. Annual Review of Psychology, 41, $1-19$.

Sturm, R. (2008). How to teach games: a general primer. [online] Retrieved from: http://www.boardgamegeek.com/thread/299189/how-to-teach-games-a-general-primer

Sturm, R. (2010). The how to play podcast page 2 . [online] https://boardgamegeek.com/geeklist/52160/how-play-podcast/page/2

Sturm, R. (2015). The how to play podcast with Ryan Sturm. [online] http://howtoplaypodcast.com/

Squire, K. (2011). Video Games and Learning: Teaching and Participatory Culture in the Digital Age. Technology, Education--Connections (the TEC Series). Teachers College Press: New York.

Sweller, J. (1988). Cognitive load during problem solving: Effects on learning. Cognitive Science, 12, 257-285.

Sweller, J., van Merrienboer, J., \& Paas, F. (1998). Cognitive architecture and instructional design. Educational Psychology Review, 10, 251-296.

Thiagarajan, S. (2004, February). Six Phases of Debriefing. [Web log Comment]. Retrieved from: http://thiagi.net/archive/www/pfp/IE4H/february2004.html

Vygotsky, L. S. (1978). Mind in society. Cambridge, MA: Harvard University Press.

\section{Turkish Abstract}

\section{Geçit Stratejileri Masaüstü Oyunlarını Öğretmede Deneyimsel Öğrenme Modelininin} Uygulanması

Masaüstü oyunları hobisi hızlı bir şekilde artmaktadır ve son zamanlarda dönüşüm yaşadı, fakat birçok dijital olmayan oyunlar ipuçlarından ve öğretici derslerden yoksundur, ayrıca öğrenmesi ve etkili öğretilmesi zor olarak durmaktadır. Bu projede, modern strateji oyunlarını klasik deneyimsel öğrenme bileşenleriyle (gösterme, gözlem, yansıtma, tartışma ve tekrarlı deneyimler) öğretmek için popüler bir hobici yaklaşımı entegre ettik. Modelimizi Japon lise ve üniversite 
öğrencilerine iki modern masaüstü oyununu öğreterek test ettik. Anketler, oyun verileri, özpuanlamalar ve tartışmalar anlama, zevk alma, daha stratejik oynama, öğretim sırasında modern masaüstü oyunlara daha fazla ilgi olduğunu gösterdi. Modelin tekrarı (katılımcılar oyunu üç kere oynadı) oyunu öğrenme konusunda en kullanışlı olarak puanlandı.Genel olarak model yeni oyunculara strateji masaüstü oyunlarını öğretmede entegre model oldukça başarıll, ve öğretmenler, tasarımcılar ve araştırmacılar için bazı öneriler sunuyoruz.

Anahtar Kelimeler: deneyimsel öğrenme, masaüstü oyunları, etkili öğretim, kavramsal yük, acemi öğrenciler

\section{French Abstract}

Application d'un Modèle d'Apprentissage Résultant de l'expérience à l'Enseignement de Jeux de Société de Stratégie de Passerelle

Le passe-temps de jeu de société a rapidement cultivé et s'est développé ces dernières années, mais les bouts de manque de jeux les plus non-numériques et des classes de travaux dirigés et reste difficile d'apprendre et enseigner effectivement. Dans ce projet, nous avons intégré une approche d'amateur populaire à l'enseignement de jeux de stratégie modernes avec des éléments d'apprentissage résultant de l'expérience classiques (c'est-à-dire, la démonstration, l'observation, la réflexion, la discussion et avons répété des expériences). Nous avons testé notre modèle en enseignant deux jeux de société modernes au lycée japonais et des étudiants universitaires. Les questionnaires, des données de jeu, des auto-évaluations et des discussions ont montré la compréhension améliorée et le plaisir, le jeu plus stratégique et plus d'intérêt dans des jeux de société modernes pour la durée de l'ordre d'instruction. La répétition du modèle (les participants a joué chaque jeu trois fois) ont été évaluées les plus utiles en termes d'apprendre les jeux. En général le modèle intégré était en grande partie réussi dans des jeux de société de stratégie enseignants à de nouveaux acteurs(joueurs) et nous offrons plusieurs recommandations pour des professeurs, des concepteurs et les chercheurs de jeux de société.

Mots Clés: apprentissage résultant de l'expérience, jeux de société, instruction effective, charge cognitive, apprenants de novice

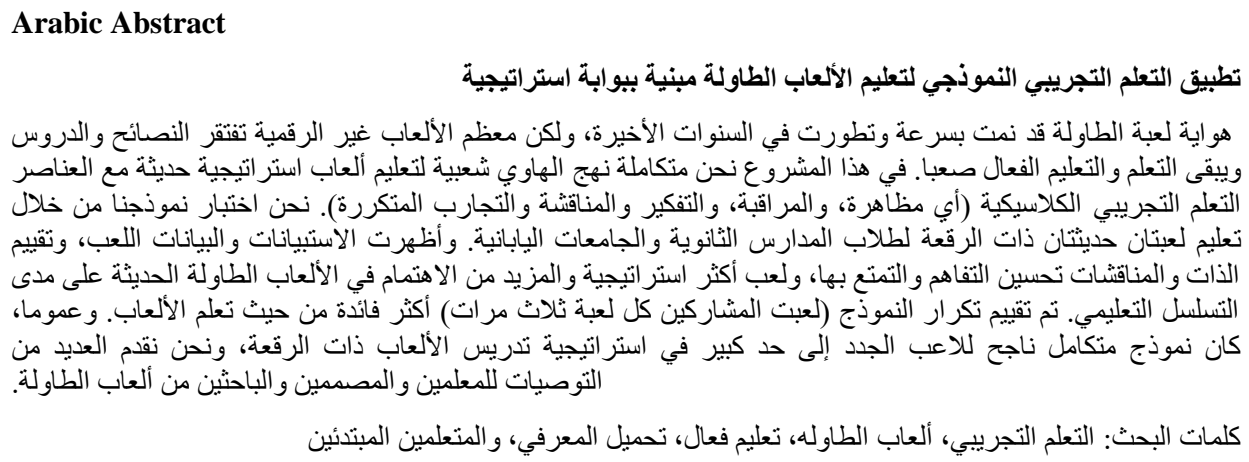

